\title{
Estimating illegal catch of abalone and lobster along the coast of the Baja California Peninsula
}

\section{Estimación de la captura ilegal de abulón y langosta en la costa de la península de Baja California}

\author{
Germán Ponce-Díaz ${ }^{1}$, Francisco Arreguín-Sánchez ${ }^{1}$, Alfredo Hernández-Llamas²*, Pablo del Monte-Luna ${ }^{1}$ \\ Mario Ramade-Villanueva ${ }^{3}$ \\ ${ }^{1}$ Instituto Politécnico Nacional, Centro Interdisciplinario de Ciencias Marinas, Av. Instituto Politécnico \\ Nacional s/n, Col. Playa Palo de Santa Rita Sur, La Paz, Baja California Sur 23096, México. \\ ${ }^{2}$ Centro de Investigaciones Biológicas del Noroeste, Mar Bermejo 195, Col. Playa Palo de Santa Rita Sur, \\ La Paz, Baja California Sur 23096, México. \\ ${ }^{3}$ Federación Regional de Sociedades Cooperativas de la Industria Pesquera “Baja California”, Calle 2da y Soto \\ No. 283, Ensenada, Baja California 22830, México.
}

* Corresponding author. E-mail: ahllamas04@cibnor.mx

\begin{abstract}
Illegal catch of abalone and lobster along the west coast of the Baja California Peninsula (Mexico) was estimated from surveys conducted among fishers and data of custom duties on live lobster exported to the USA. We estimated that illegal catch of abalone amounts to $62 \mathrm{t} \mathrm{yr}^{-1}$ (27\% of the commercial catch) and illegal catch of lobster amounts to $64 \mathrm{t} \mathrm{yr}^{-1}$ (5\% of the commercial catch). The two methods used in this study to estimate the illegal lobster catch yielded similar and consistent results ( $4.7 \%$ of the legal catch when using survey data and $4.5 \%$ when using data on custom duties for 1989-2002). We conclude that the methods of estimation are useful and reliable because they are based on direct sources of information. The methods could be used for a bottom-up approach to estimate illegal catch.
\end{abstract}

Key words: illegal catch, poaching, abalone, lobster.

RESUMEN. Se estimó la captura ilegal de abulón y langosta en la costa oeste de la península de Baja California (México) a partir de encuestas entre pescadores e información sobre aranceles correspondiente a langosta viva exportada a los Estados Unidos. Se estimó que la captura ilegal de abulón asciende a 62 t año ${ }^{-1}$ (27\% de la captura comercial) y la captura ilegal de langosta asciende a 64 t año ${ }^{-1}$ (5\% de la captura comercial). Los dos métodos utilizados para estimar la captura ilegal de langosta arrojaron resultados similares y consistentes (4.7\% de la captura legal usando datos de las encuestas y 4.5\% usando información sobre aranceles de 1989 a 2002). Se concluye que los métodos de estimación son útiles y confiables porque se basan en fuentes directas de información. Los métodos pueden ser usados para un enfoque ascendente (bottom-up approach) en la estimación de captura ilegal.

Palabras clave: captura ilegal, pesca ilegal, abulón, langosta.

\section{INTRODUCTION}

Illegal, unreported, and unregulated (IUU) fishing is carried out practically in all fishing areas. It represents a direct and important threat to species conservation and efficient management of many fisheries, and has negative consequences for people making a living from legal fishing (FAO 2002a). IUU fishing is receiving greater attention from international and national organizations and government fisheries agencies (FAO 2002a, 2002b, 2005; OECD 2004; Ainsworth and Pitcher 2005; WWF 2006; SAGARPA 2006; Agnew et al. 2009).

Fish catches are commonly reported at landing without considering illegal fishing, discarded fish, or unregulated catch, implicitly assuming that these practices do not occur or that they are zero. Pitcher et al. (2002) postulate that an assumption of zero IUU fishing is unacceptable, calling for

\section{INTRODUCCIÓN}

La pesca ilegal, no reportada y no regulada (IUU por sus siglas en inglés) se realiza en casi todas las zonas de pesca. Representa una amenaza directa e importante para la conservación de especies y el manejo eficiente de diversas pesquerías, y tiene consecuencias negativas para las personas que viven de la pesca legal (FAO 2002a). La pesca IUU está recibiendo mayor atención por parte de organizaciones internacionales y nacionales y de agencias gubernamentales (FAO 2002a, 2002b, 2005; OECD 2004; Ainsworth y Pitcher 2005; WWF 2006; SAGARPA 2006; Agnew et al. 2009).

Las capturas pesqueras comúnmente se registran durante el desembarque sin considerar la pesca ilegal, los descartes o la captura no regulada, dando a entender que estas prácticas no se llevan a cabo. Pitcher et al. (2002) postulan que una suposición de cero pesca IUU es inaceptable y sugieren 
complementary methods to estimate total catch and the true effect on fish mortality.

We use the concept of illegal catch that corresponds to the first category of illegal catch, as defined by FAO (2002a): the catch carried-out by boats in waters under the jurisdiction of a State, without having a permit and contravening its laws and regulations.

Illegal fishing of abalone (Haliotis spp.) and red lobster (Panulirus interruptus) along the west coast of the Baja California Peninsula (Mexico) is considered important, seriously limiting any effort at conservation and responsible fisheries management. Illegal fishing of abalone has been estimated at $0.8 \mathrm{t} \mathrm{yr}^{-1}$ (Ponce-Díaz et al. 2003), $1.5 \mathrm{t} \mathrm{yr}^{-1}$ (Gordon and Cook 2004), and 550 and $400 \mathrm{t} \mathrm{yr}^{-1}$ (Redona 2003). In the case of red lobster, an illegal catch of $15 \%$ of the authorized catch was estimated (Chaffee 2003). These reports, however, do not describe the method of estimation and are based on anecdotal and subjective sources; thus, the estimates are unreliable.

According to MRAG (2005), the methods used for estimating IUU fishing can be classified as: (1) top-down approaches that result in global estimates directly, and (2) bottom-up approaches that focus on adding estimates made from more detailed information at a lower scale. We present the results obtained on a local scale that could be used for a bottom-up approach. We use estimation methods of illegal catches of abalone and lobster off the Baja California Peninsula that, compared to previous reports, yield more reliable estimates of illegal catches. Illegal abalone catch was estimated from a survey conducted among fishers working in the fishing areas. Illegal lobster catch was estimated by using data from a survey conducted among fishers and data of custom duties corresponding to live lobster traded in the USA during closed seasons. A probabilistic approach was used to deal with the estimates of illegal catch by fitting empirical and theoretical distributions to the data. In the reviewed literature, we did not find antecedents of the use of the same probabilistic approach that we applied to analyze estimates of illegal catch.

\section{MATERIALS AND METHODS}

\section{Study area and survey}

Abalone and lobster fishing is mainly carried out between Isla Cedros and Punta Abreojos on the central west coast of the Baja California Peninsula (fig. 1), where nine fishing cooperatives with $\sim 1200$ members work (Ponce-Díaz et al. 1998). In 2005, a survey of 202 fishers was conducted. Questionnaires were prepared containing 14 questions regarding age, gender, and residence, and 26 questions regarding illegal fishing of abalone and lobster, particularly their estimates of the number of illegal boats operating in the area each day and the total catch obtained per boat. The number of interviewed implementar métodos complementarios para estimar la captura total y el efecto real en la mortalidad por pesca.

El concepto de captura ilegal que nosotros usamos corresponde a la primera categoría de captura ilegal que define la FAO (2002a): la captura realizada por embarcaciones en aguas bajo la jurisdicción de un Estado, sin el permiso de éste o contraviniendo sus leyes y reglamentos.

La pesca ilegal de abulón (Haliotis spp.) y langosta roja (Panulirus interruptus) en la costa oeste de la península de Baja California (México) se considera importante y seriamente limita cualquier esfuerzo de conservación y manejo responsable de estos recursos pesqueros. La pesca ilegal de abulón ha sido estimada en $0.8 \mathrm{t}$ año ${ }^{-1}$ (Ponce-Díaz et al. 2003), 1.5 t año ${ }^{-1}$ (Gordon y Cook 2004), y 550 y 400 t año ${ }^{-1}$ (Redona 2003). Para la langosta roja, se estimó una captura ilegal de 15\% de la pesca autorizada (Chaffee 2003). Estos reportes, sin embargo, no describen el método de estimación y se basan en fuentes anectódicas y subjetivas; por lo tanto, no son confiables.

Según MRAG (2005), los métodos empleados para estimar la pesca IUU pueden clasificarse como: (1) enfoques descendentes (top-down) que proporcionan estimaciones globales directamente y (2) enfoques ascendentes (bottomup) que se centran en la adición de estimaciones realizadas a partir de información más detallada en una escala inferior. Aquí presentamos los resultados obtenidos a escala local que podrían usarse para un enfoque ascendente. Se usaron métodos para estimar las capturas ilegales de abulón y langosta en la costa de la península de Baja California que, en comparación con otros estudios, proporcionan estimaciones más confiables de las capturas ilegales. La captura ilegal de abulón se estimó a partir de una encuesta realizada a pescadores que trabajan en las zonas de pesca. La captura ilegal de langosta se estimó a partir de una encuesta realizada a pescadores y de información arancelaria sobre langosta viva exportada a los Estados Unidos durante épocas de veda. Se usó un enfoque probabilístico para realizar las estimaciones de captura ilegal mediante el ajuste de distribuciones empíricas y teóricas a los datos. En la literatura revisada, no se encontraron antecedentes del uso del mismo enfoque probabilístico que usamos para analizar las estimaciones de captura ilegal.

\section{MATERIALES Y MÉTODOS}

\section{Área de estudio y encuesta}

La pesca de abulón y langosta se realiza principalmente entre la isla de Cedros y punta Abreojos en la costa oeste central de la península de Baja California (fig. 1), donde trabajan nueve cooperativas pesqueras con $\sim 1200$ miembros (PonceDíaz et al. 1998). En 2005, se realizó una encuesta a 202 pescadores. Los cuestionarios consistieron de 14 preguntas sobre edad, género y residencia, y 26 preguntas sobre la pesca ilegal de abulón y langosta, particularmente sobre sus estimaciones del número de embarcaciones ilegales que 
fishers at the fishing communities was established according to the number of fishers working at each community: Bahía Tortugas (33\%), Punta Abreojos (21\%), Bahía Asunción (19\%), Isla Cedros (13\%), Isla Natividad (6\%), Punta Prieta (5\%), and La Bocana (3\%).

\section{Estimating illegal and total catch of abalone}

Annual illegal catch of abalone was estimated by multiplying by 365 days the daily illegal estimated catch provided by the survey. Theoretical probability distributions were fitted to data of the illegal catch using @Risk 4.0 (Palisade, Ithaca, NY) and Crystal Ball 7.0 (Oracle, Redwood Shores, CA), but the distributions available in these packages did not yield a satisfactory fit; therefore, a customized probability distribution was used. Total catch was calculated by adding the illegal catch to the official reports.

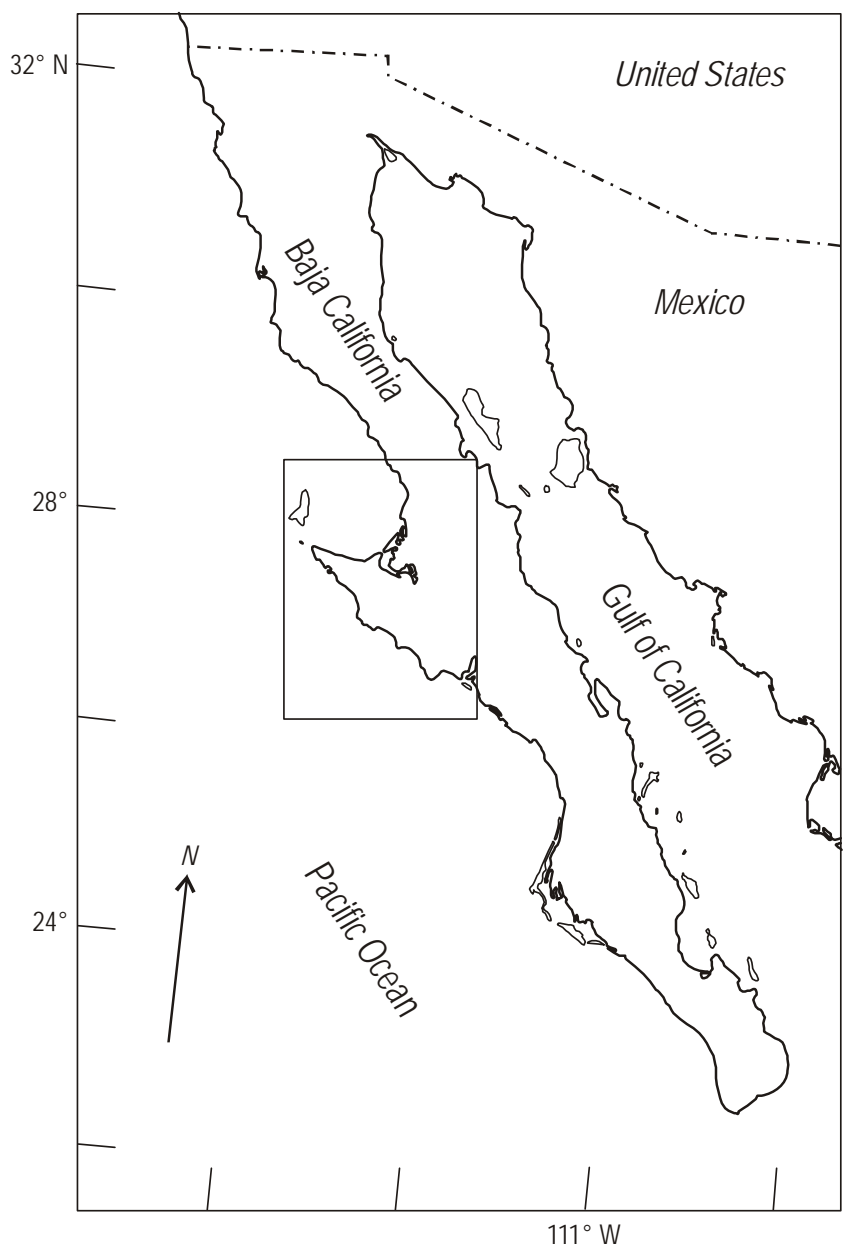

Figure 1. Study area on the west coast of the Baja California Peninsula (Mexico).

Figura 1. Área de estudio en la costa occidental de la península de Baja California (México). operan en la zona cada día y la captura total obtenida por cada embarcación. El número de pescadores entrevistados en las comunidades se estableció según el número de pescadores trabajando en cada lugar: bahía Tortugas (33\%), punta Abreojos (21\%), bahía Asunción (19\%), isla Cedros (13\%), isla Natividad (6\%), punta Prieta (5\%) y La Bocana (3\%).

\section{Estimación de la captura ilegal y total de abulón}

La captura ilegal anual de abulón se estimó multiplicando por 365 días la captura ilegal diaria estimada a partir de la encuesta. Las distribuciones teóricas de probabilidad fueron ajustadas a los datos de pesca ilegal con los programas @ Risk 4.0 (Palisade, Ithaca, NY) y Crystal Ball 7.0 (Oracle, Redwood Shores, CA), pero las distribuciones disponibles en éstos no arrojaron un ajuste satisfactorio; por lo tanto, se usó una distribución de probabilidad adaptada. La captura total se calculó sumando la captura ilegal a los registros oficiales.

\section{Estimación de la captura ilegal y total de langosta}

Se usaron dos métodos para realizar las estimaciones. Uno fue el mismo que se usó para el abulón, donde las distribuciones de probabilidad adaptadas fueron ajustadas a los datos de captura ilegal después de que las distribuciones teóricas no proporcionaron un ajuste satisfactorio. El segundo método usó datos sobre aranceles a langosta (género Panulirus) viva exportada a los Estados Unidos durante las épocas de veda de 1989 a 2002 (NOAA 2006). Se considera válido usar datos de langosta viva exportada durante las épocas de veda para estimar la captura ilegal ya que la mayor parte de la langosta de México se exporta a los Estados Unidos y la mayoría es langosta viva (Chaffee 2003). Usando Crystal Ball 7.0, se ajustó una distribución teórica a la captura ilegal. La captura total se estimó mediante la suma de los valores estocásticos de captura ilegal, generados por el método de muestreo Monte Carlo, a los registros oficiales.

\section{RESUltados}

Se obtuvieron distribuciones de probabilidad para las capturas ilegales y totales durante 2005 de abulón (fig. 2) y langosta (fig. 3). Para abulón, la captura oficial fue 235 t, y la captura ilegal y captura total promedio fueron $62.5 \mathrm{t}$ y 297.5 t, respectivamente. Se obtuvo un límite máximo de confianza al $95 \%$ para la captura total de 333.4 t. En cuanto a la captura total promedio, se determinó una subestimación por parte de los registros oficiales de 26.8\%. Para langosta, la captura oficial fue $1337.6 \mathrm{t}$, la captura ilegal fue $63.8 \mathrm{t}$ y la captura total fue 1401.4 t, y el límite máximo de confianza al 95\% se estimó en 1431.5 t. Se calculó una subestimación por parte de los registros oficiales de $4.7 \%$.

Entre las distribuciones teóricas disponibles en @Risk 5.0, la distribución lognormal mostró el mejor ajuste para la captura ilegal de langosta estimada con información arancelaria de Estados Unidos. Se estableció la distribución de 


\section{Estimating illegal and total catch of lobster}

Two methods were used for making estimates. One was the same as that used for abalone, where customized probability distributions were fitted to the illegal catch data after no theoretical distributions yielded a satisfactory fit. The other method used data on custom duties for live lobster (genus Panulirus) exported to the USA during closed seasons (1989-2002, NOAA 2006). There are valid reasons for considering live lobster exported during closed seasons to estimate illegal catch because most lobster from Mexico is exported to the USA and most is live lobster (Chaffee 2003). Using Crystal Ball 7.0, a theoretical distribution was fitted to the illegal catch. Total catch was estimated by adding stochastic values of illegal catch, generated by the Monte Carlo sampling technique, to the official reports.

\section{RESULTS}

Probability distributions for illegal and total catches during 2005 were obtained for abalone and lobster fisheries (figs. 2 and 3, respectively). The official catch for abalone was $235 \mathrm{t}$ and the estimated mean illegal and total catches were $62.5 \mathrm{t}$ and $297.5 \mathrm{t}$, respectively. A maximum 95\% confidence limit for total catch was $333.4 \mathrm{t}$. In relation to mean total catch, an underestimation of $26.8 \%$ by the official reports was determined. For the lobster fishery, the official, illegal, and total catches were 1337.6, 63.8, and $1401.4 \mathrm{t}$, respectively, and the maximum 95\% confidence limit was

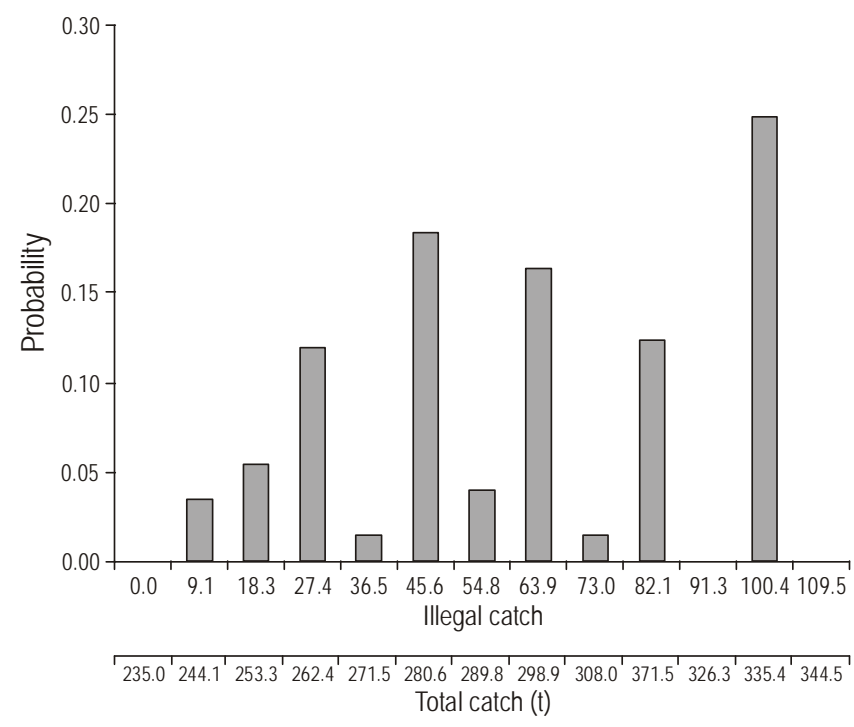

Figure 2. Probability of illegal and total abalone catch. Total catches were calculated by adding the illegal catch to the official reports.

Figura 2. Probabilidad de la captura ilegal y total de abulón. Las capturas totales se calcularon sumando la captura ilegal a los registros oficiales. probabilidad de la captura total y la captura ilegal mediante el método Monte Carlo. La captura legal fue 1298 t y la captura ilegal y captura total promedio fueron 16 y 1314 t, respectivamente. Se estimó un límite de confianza al 95\% en 1346 t. Esto resulta en una subestimación de $\sim 1.2 \%$ de la captura total promedio con base en las estimaciones de captura legal y de $3.7 \%$ con base en el límite de confianza al 95\%.

Se estimó la captura ilegal y total, así como el límite de confianza al 95\% de la captura total de langosta, para el periodo de 1989 a 2002 mediante la distribución teórica lognormal (figs. 4, 5). Para la captura total promedio, la subestimación con base en las estimaciones de la captura legal varió de $3.11 \%$ a $6.1 \%$, con un promedio de $4.5 \%$ durante este periodo.

\section{DISCUSIÓN}

La captura ilegal de abulón en 2005 se estimó en 63 t, 27\% de las 235 t de captura legal para ese año (Rubén García, com. pers., Comité de Supervisión de la Federación Regional de Sociedades Cooperativas de la Industria Pesquera "Baja California”). Otras estimaciones para la captura ilegal en la misma zona son muy variables, de $0.8 \mathrm{t}$ (Ponce-Díaz et al. 2003) hasta 400 y 550 t año ${ }^{-1}$ (Redona 2003, Gordon y Cook 2004); sin embargo, tales estimaciones se basaron en fuentes anectódicas y subjetivas. Nuestras estimaciones se consideran más confiables porque se usó una fuente directa, con base en la experiencia de gente involucrada directamente en la protección de las poblaciones de abulón.

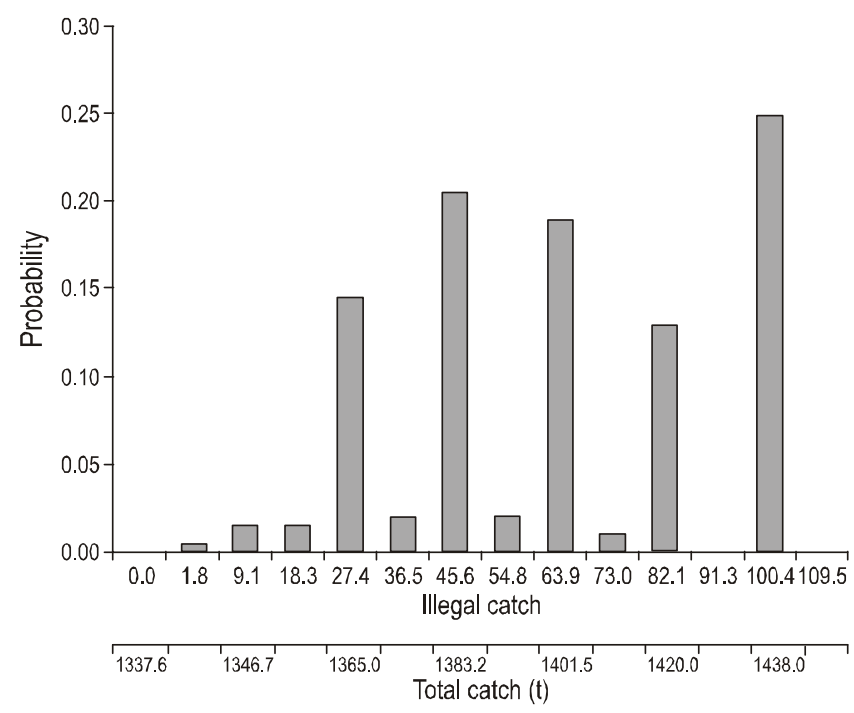

Figure 3. Probability of illegal and total lobster catch. Total catches were calculated by adding the illegal catch to the official reports.

Figura 3. Probabilidad de la captura ilegal y total de langosta. Las capturas totales se calcularon sumando la captura ilegal a los registros oficiales. 
estimated at $1431.5 \mathrm{t}$. An underestimation by the official report was calculated as $4.7 \%$.

Among theoretical distributions available in @Risk 5.0, the log-normal distribution showed the best fit for the estimated illegal catch of lobster, using data from US custom duties. The probability distribution of total and illegal catches, using the Monte Carlo technique, was established for 2002. Legal catch was $1298 \mathrm{t}$ and mean illegal catch and total catch were 16 and 1314 t, respectively. A 95\% confidence limit for total catch was estimated at $1346 \mathrm{t}$. This results in an underestimation of $\sim 1.2 \%$ in mean total catch from the legal catch estimates and 3.7\% underestimation based on the 95\% confidence limit.

Illegal and total catch, as well as the 95\% confidence limit of the lobster total catch, was estimated for 1989-2002, using the log-normal theoretical distribution (figs. 4, 5). Overall, in relation to mean total catch, underestimation based on legal catch estimates ranged from $3.11 \%$ to $6.1 \%$, with a mean of $4.5 \%$ during this period.

\section{DISCUSSION}

The illegal catch of abalone in 2005 was estimated to be as high as $63 \mathrm{t}, 27 \%$ of the $235 \mathrm{t}$ for the legal catch that year (Rubén García, pers. comm., Surveillance Secretariat of the "Baja California” Regional Federation of Fisheries Cooperative Societies). Other reports that estimated the illegal catch of abalone in the same area are highly variable, ranging from $0.8 \mathrm{t}$ (Ponce-Díaz et al. 2003) to 400 and $550 \mathrm{t} \mathrm{yr}^{-1}$ (Redona 2003, Gordon and Cook 2004). It should be noted that such estimates were based on anecdotal and subjective sources. The estimates in our study are more reliable because we used a direct source, based on the experience of people directly involved in protecting the status of abalone stocks.

The Mexican abalone fishery seems to be slowly recovering since 2000, after a drastic decline from $2500 \mathrm{t}$ in the 1960s to about $250 \mathrm{t}$ by the end of the 1990s (SAGARPA 2006). This recovery is partly a consequence of managing the fishery with catch quotas, closed seasons, minimum catch size, and stock assessment with dynamic models (SAGARPA 2006).

The probability of success in abalone poaching is a factor with significant influence on fishers' perceptions of poaching. The low risk of being caught by authorities and the harvest volume per working day are elements that make abalone poaching a highly appealing activity (Bórquez-Reyes et al. 2009). High market value and vulnerability of abalone stocks are strong incentives that induce illegal fishing. A can containing $0.54 \mathrm{~kg}$ is worth US $\$ 45$; the value of the illegal catch in 2005 is estimated at US\$5.7 million on the international market. This figure is at least double the amount expended for surveillance and enforcement by the fisheries cooperatives during that year (US\$2.5 million, Rubén García, pers. comm.).

The two methods used in this study to estimate illegal catch of lobster yielded similar results (i.e., $4.7 \%$ of the legal
La pesquería de abulón en México parece estar recuperándose lentamente desde 2000, después de disminuir drásticamente desde $2500 \mathrm{t}$ en los años sesenta hasta 250 t a finales de la década de los años noventa (SAGARPA 2006). Esta recuperación se debe en parte al manejo de la pesquería mediante cuotas de captura, épocas de veda, una talla mínima de captura y la evaluación de la población con modelos dinámicos (SAGARPA 2006).

La probabilidad de éxito en la caza furtiva de abulón es un factor que influye fuertemente en la percepción de los pescadores en cuanto a la pesca ilegal. El bajo riesgo de ser capturado por las autoridades y el volumen de cosecha por

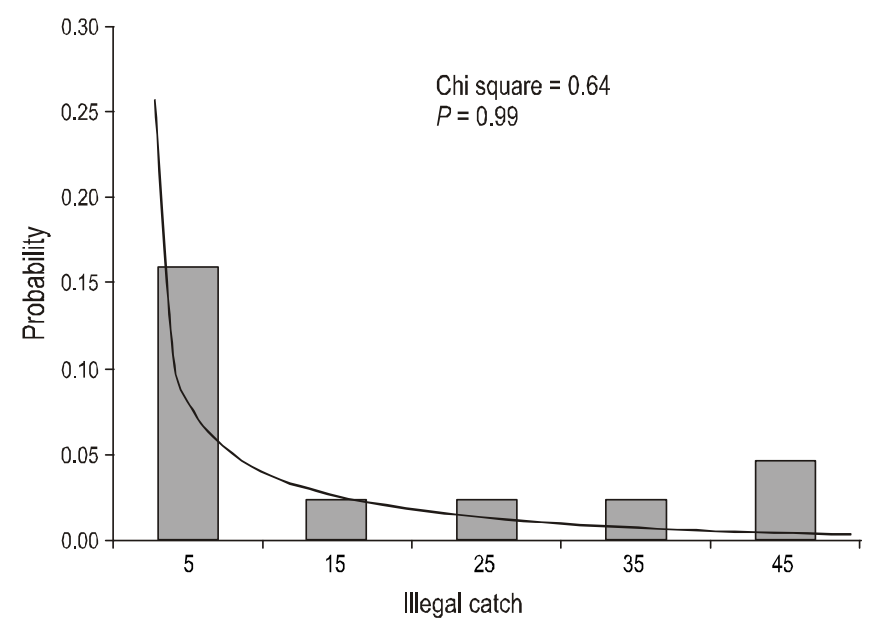

Figure 4. Fit of the log-normal distribution to data of illegal catch estimated from custom duties for 1989 to 2002.

Figura 4. Ajuste de la distribución lognormal a los datos de captura ilegal estimados a partir de datos arancelarios de 1989 a 2002.

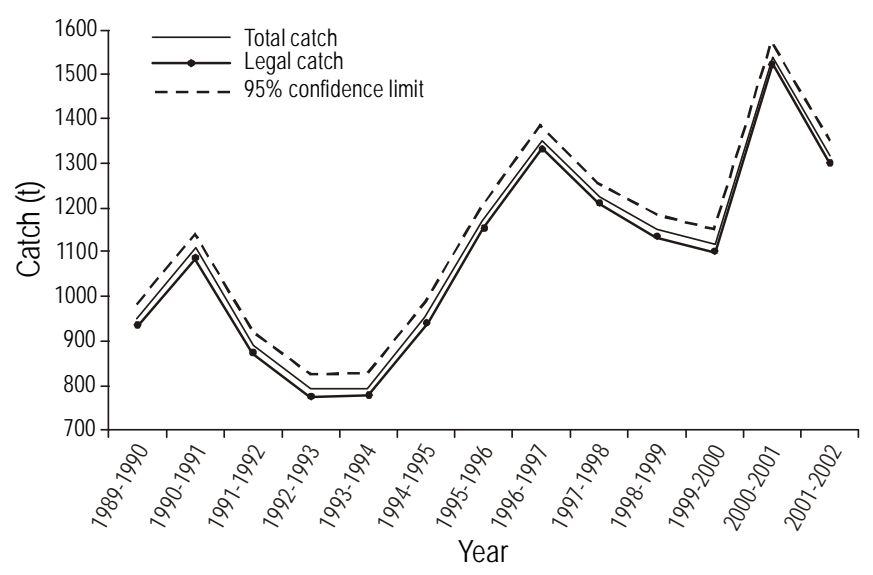

Figure 5. Legal and total catch of lobster from 1989 to 2002. The illegal catch is negligible when compared with the legal catch.

Figura 5. Captura legal y total de langosta de 1989 a 2002. La captura ilegal es insignificante en comparación con la captura legal. 
catch when using data from fishers, and 4.5\% when using data from custom duties for 1989-2002). This indicates consistency of both methods. Both estimates contrast with references estimating the illegal catch at up to $15 \%$ of legal production (Chaffee 2003).

The estimated illegal catch of lobster (4.7\% of commercial catch) was lower than the illegal catch of abalone (26.8\% of commercial catch). We attribute this to the higher vulnerability of abalone stocks to fishing activity, compared to the vulnerability of lobster stocks.

Agnew et al. (2009) estimated the worldwide extent of illegal catch at $7 \%$ of the total catch for the Northeast Pacific and $100 \%$ for the Antarctic. Our estimates of illegal catch of abalone and lobster are relatively low compared to those figures, particularly the estimate for illegal abalone catch, which is drastically lower than the estimate obtained by Plagányi et al. (2011) for the South African abalone (Haliotis midae) fishery, which rates as an extreme example of extraordinarily high levels of illegal and unreported catch (i.e., more than 10 times the total allowable catch).

We conclude that the estimation methods we used are reliable because they are based on direct sources of information. The methods proved to be adequate for estimating the illegal catch of coastal fisheries at a local level, and could be used as a bottom-up approach for estimating illegal catch.

\section{ACKNOWLEDGMENTS}

Funding was provided by SEMARNAT-CONACYT grant 2004-C01-0153, CONACYT-IPN grant I100/029/06, MOD-ORD-33-05, PCI-0 01-06, and SIP 20110114. Authors GPD, FAS, and PDM are IPN COFAA and EDI fellows. We thank Fernando López-Salas for invaluable advice and support in the field. Benito Bermúdez-Almada also provided support. At CIBNOR, Ira Fogel provided editing services and Gerardo Hernández helped in preparing the figures. Important support and participation was received from the Surveillance Secretariat of the "Baja California" Regional Federation of Fisheries Cooperative Societies and its member cooperatives.

\section{REFERENCES}

Agnew DJ, Pearce J, Pramod G, Peatman T, Watson R, Beddington JR, Pitcher TJ. 2009. Estimating the worldwide extent of illegal fishing. PlosONE 4(2): e4570. http://dx.doi.org/10.1371/journal.pone.0004570.g001

Ainsworth CH, Pitcher TJ. 2005. Estimating illegal, unreported and unregulated catch in British Columbia's marine fisheries. Fish. Res. 75: 40-55. http://dx.doi.org/10.1016/j.fishres.2005.05.003

Bórquez-Reyes R, Pombo OA, Ponce-Díaz G. 2009. Fishers' reasons for poaching abalone (Haliotidae): A study in the Baja California Peninsula, Mexico. N. Am. J. Fish. Manage. 29(1): 237-244.

http://dx.doi.org/10.1577/M06-032.1

Chaffee C. 2003. An assessment of the red rock lobster fishery, Baja California, Mexico. Draft for public comment. Scientific Certification System, Oakland, CA, USA. jornada laboral son elementos que convierten la pesca ilegal de abulón en una actividad muy atractiva (Bórquez-Reyes et al. 2009). El alto valor en el mercado y la vulnerabilidad de las poblaciones de abulón son fuertes incentivos que promueven la pesca ilegal. Una lata con $0.54 \mathrm{~kg}$ vale US $\$ 45$; el valor de la captura ilegal en 2005 se estimó en US\$5.7 millones en el mercado internacional. Esta cifra es al menos el doble el monto invertido durante ese año por las cooperativas pesqueras en la vigilancia y el cumplimiento de las normas establecidas (US\$2.5 millones, Rubén García, com. pers.).

Los dos métodos empleados para estimar la captura ilegal de langosta arrojaron resultados similares (i.e., $4.7 \%$ de la captura legal cuando se usaron datos de las encuestas y $4.5 \%$ cuando se usó información arancelaria de 1989 a 2002). Esto indica consistencia en los dos métodos. Ambas estimaciones contrastan con otras estimaciones de captura ilegal de hasta 15\% de la producción legal (Chaffee 2003).

La captura ilegal estimada de langosta $(4.7 \%$ de la captura comercial) fue menor que la captura ilegal de abulón (26.8\% de la captura comercial). Esto se atribuye a la mayor vulnerabilidad a la pesca de las poblaciones de abulón en comparación con las poblaciones de langosta.

Agnew et al. (2009) estimaron el grado de pesca ilegal a nivel mundial y documentaron $7 \%$ de la captura total para el Pacífico nororiental y 100\% para el océano Antártico. Nuestras estimaciones para la captura ilegal de abulón y langosta son relativamente bajas en comparación con esas cifras. En particular, nuestra estimación para la captura ilegal de abulón es mucho menor que la obtenida por Plagányi et al. (2011) para la pesca de abulón (Haliotis midae) en Sudáfrica, que es un ejemplo extremo de niveles extraordinariamente altos de pesca ilegal y no reportada (i.e., más de 10 veces la captura total permisible).

En conclusión, los métodos de estimación usados son confiables porque se basan en fuentes directas de información. Los métodos resultaron ser adecuados para estimar la captura ilegal de pesquerías costeras a nivel local y pueden ser usados para un enfoque ascendente (bottom-up) en la estimación de la captura ilegal.

\section{Agradecimientos}

Este estudio fue apoyado por los siguientes proyectos: SEMARNAT-CONACYT 2004-C01-0153, CONACYT-IPN I100/029/06, MOD-ORD-33-05, PCI-0 01-06, y SIP 20110114. Los autores GPD, FAS y PDM agradecen el apoyo recibido a través de los programas COFAA y EDI del IPN. Se agradece a Fernando López-Salas sus valiosas sugerencias y su asistencia en el campo, así como el apoyo proporcionado por Benito Bermúdez-Almada. En CIBNOR, Ira Fogel proporcionó apoyo editorial y Gerardo Hernández ayudó a preparar las figuras. Se reconoce la importante participación y el apoyo brindado por la Federación Regional de Sociedades Cooperativas de la Industria Pesquera "Baja California”.

Traducido al español por Christine Harris. 
FAO. 2002a. Aplicación del plan de acción internacional para prevenir, desalentar y eliminar la pesca ilegal, no declarada y no reglamentada. Orientaciones Técnicas para la Pesca Responsable No. 9, FAO, Roma, 141 pp.

FAO. 2002b. Acabar con la pesca no declarada y no reglamentada. FAO, Roma, 28 pp.

FAO. 2005. Declaración de Roma de 2005 sobre la pesca ilegal, no declarada y no reportada. Reunión Ministerial de la FAO sobre Pesca, 12 de marzo de 2005, Roma, 5 pp.

Gordon HR, Cook PA. 2004. World abalone fisheries and aquaculture update: Supply and market dynamics. J. Shellfish Res. 23: 935-939.

MRAG. 2005. Review of Impacts of Illegal, Unreported and Unregulated Fishing on Developing Countries. Marine Resources Assessment Group, London, http://www.dfid.gov.uk/ pubs/files/illegal-fishing-mrag-report.pdf. Accessed 20 January 2013.

NOAA. 2006. http//www.nooa.gov. (accessed April 2007).

OECD. 2004. Fish piracy. Combating illegal, unreported and unregulated fishing. Organization for Economic Co-operation and Development, Paris, 406 pp.

Pitcher TJ, Watson R, Forrest R, Valtýsson H, Guénette S. 2002. Estimating illegal and unreported catches from marine ecosystems: A basis for change. Fish Fish. 3: 317-339. http://dx.doi.org/10.1046/j.1467-2979.2002.00093.x

Plagányi É, Butterworth D, Burgener M. 2011. Illegal and unreported fishing on abalone-Quantifying the extent using a fully integrated assessment model. Fish. Res. 107: 221-232. http://dx.doi.org/10.1016/j.fishres.2010.11.005

Ponce-Díaz G, Vega-Velázquez A, Ramade-Villanueva M, LeónCarballo G, Franco-Santiago R. 1998. Socioeconomic characteristics of the abalone fishery along the west coast of Baja California Peninsula, Mexico. J. Shellfish Res. 17: 853-857.

Ponce-Díaz G. Sánchez-Hernández S, Moctezuma-Cano T, OlguínEspinoza I, Serviere-Zaragoza E, Pérez-Enríquez R, HernándezLlamas A, Ramade-Villanueva M, Lluch-Cota D, Lluch-Cota S, Hernández-Vázquez S, de Anda-Montañéz A, González-Angulo M, Soria-Martínez G, García-Domínguez G, Beltrán-Morales LF, Flores-Quintana E, González-Becerril A. 2003. Estudio de la Cadena Productiva de Abulón. CONAPESCA, CIBNOR, BANCOMEXT, 215 pp.

Redona L. 2003. Diario El Peninsular, La Paz, Baja California Sur, México. 20 de mayo de 2003. No. 4610.

SAGARPA. 2006. Sustentabilidad y pesca responsable en México. Evaluación y manejo. Secretaría de Agricultura, Ganadería, Desarrollo Rural, Pesca y Alimentación. http:// www.inp.sagarpa.gob.mx/Publicaciones/sustentabilidad/2006/ libro_Rojo.pdf

WWF. 2006. World Wildlife Fund's Community-Based Certification Program: Engaging Small-scale Fishers in the MSC Eco-label Process. http://assets.panda.org/downloads/ final_cbc_fact_sheet.pdf (accessed 21 June 2007).

Received August 2012, received in revised form February 2013, accepted February 2013. 